Acta medico-historica Rigensia (2020) XIII: 29-57

doi:10.25143/amhr.2020.XIII.03

Tomas Vaiseta

\title{
Power unto Sickness, Sickness unto Power in the Periphery of Soviet Psychiatry
}

\section{Abstract}

The three most important processes in psychiatric hospitals of the Lithuanian SSR (1944-1990) have been analysed in terms of the centreperiphery relation. Two of them are named "power unto sickness", that is, the Soviet state's efforts to influence people with deviant behaviours who were considered to have "mental diseases". The first process could be considered external: institutionalisation of psychiatric system in the Lithuanian SSR that was meant to create the conditions, forms and means to exercise the said influence. The main outcome of the process is said to be the so-called "institution addiction" where problems arising from institutionalisation are tackled with more institutionalisation. The second process in the "power unto sickness" category is internal. The Soviet psychiatric model used in the Lithuanian SSR has been analysed and the question whether there has ever been a homogenous and unique model of Soviet psychiatry has been raised. The third process is the symbolic inverse of the "power unto sickness" processes, but determined by them - "sickness unto power". It shows the "power" itself to be deviant, transgressing formal limits, exposes the consequences and cracks of its exercise. The third process in psychiatric hospitals of the Lithuanian SSR, "parallelisation", in which the modern hospital, alongside its formal therapeutic function, acquired parallel, nonformal functions, has been described.

Keywords: Lithuanian SSR, Soviet Union, psychiatry, psychiatric hospital, institutionalisation, parallelisation. 


\section{Introduction}

In the wake of the Bolshevik coup, the Soviet state developed a free universal healthcare system. Alongside other socialist programmes, it was one of the central tools for sovietisation. More than the building of a welfare state-like model, it represented total statisation, i.e., a push for complete state control. The Soviet healthcare system is often referred to by the name of its architect, the People's Commissar of Public Health Nikolai Semashko. His model depended on elimination of the private sector, strict centralisation under the state and a network of healthcare institutions along the territorial-geographic principle. Under this model, the Soviet regime sought to install a healthcare system through extensive institutionalisation. The state would set up hierarchical healthcare institutions ranked by competences and services they provided. This way, after eliminating any alternatives offered by the private sector or communities, the staterun institution became the cornerstone of the system and ensured that this system and all its branches came under its total subordination. In this sense, "universally accessible" health services were also essentially "universally compulsory".

This healthcare model would be reproduced in the countries annexed by the Soviet Union during World War Two. Monolithic in theory, the system would, nevertheless, have variations, differences and particular characteristics in each republic. This article will explore one Sovietoccupied country, Lithuania (first occupation in 1940, second in 1944), focusing on a single part of the healthcare system installed there, psychiatry. It, too, underwent an extensive institutional development. The process of radical institutionalisation meant setting up stationary care institutions where "inmates are isolated from the community and are forced to live together; they do not exert any control over their lives nor take part in making the decision that concern them; institutional rules take precedence over inmates' needs"1. The Soviet state sought to make sure that there were no, at least manifestly, deviant individuals in the population and that all the sick ones be attended to and, if necessary, hospitalised in state-run institutions. Psychiatric hospitals, therefore, were the central element of the system.

1 Dainius Pūras, Eglè Šumskienè, Ǐššukiai igyvendinant Lietuvos psichikos sveikatos politiką: Mokslo studija (Vilnius: Vilniaus universiteto leidykla, 2013), 72. 
The article aims to describe the most important processes in the psychiatric hospitals of the Lithuanian SSR and analyse them in terms of the centreperiphery relation, i.e., look at how the model dictated from the Soviet centre was adopted by one Soviet republic and how it affected the development of its psychiatric system during the entire period of the occupation (1944-1990). This article is based on several chapters in the book Summerhouse: The Social History of Vilnius Psychiatric Hospital (1944-1990)2, published in Lithuanian. The study relies on several sources: archival documents (the LSSR Health Ministry Collection at the Lithuanian Central State Archives; Vilnius Psychiatric Hospital Collection; Vilnius City Mental Health Centre Archive; the KGB collections of the Lithuanian Special Archives), 27 semi-structured interviews with former employees of psychiatric hospitals (psychiatrists, psychotherapists, nurses) and former patients (identified by initials only), published memoirs of doctors and patients, contemporary press publications (from during the war period, the Soviet occupation period and after Lithuania's independence).

The analysis is presented in two parts. First, analysis of the processes that the Author prefers to call "power unto sickness", that is, the Soviet state's efforts to influence (control, supervise, change, "treat") people with deviant behaviours who were considered to have "mental diseases" according to the prevailing understanding of the time. Two processes are of particular interest to the Author. The first one could be considered external: institutionalisation of the psychiatric system in the Lithuanian SSR that was meant to create the conditions, forms and means to exercise the said influence. It should be noted that the concept of institutionalisation in this part of the article will be understood only as a form of organising a psychiatric system. That is, only the conditions for institutional treatment (the expansion of institutions) will be analysed, leaving the inner processes of institutionalisation (such as its effect on inmates, as mentioned in the definition given above) aside. The main outcome of the radical institutionalisation run by the Soviet state is said to be the so-called "institution addiction" where problems arising from institutionalisation are tackled with more institutionalisation. The second process in the "power unto sickness" category is internal. The focus here is the Soviet psychiatric model used in the Lithuanian SSR,

2 Tomas Vaiseta, Vasarnamis: Vilniaus psichiatrijos ligoninès socialine istorija (1944-1990) (Vilnius: Lapas, 2018). 
i.e., one version of the aetiology, explanation and interpretation of a person's deviant behaviour, inner world and "mental diseases" and the resulting practical therapeutic methods. The question raised is whether there ever had been a homogenous and unique model of Soviet psychiatry.

In the second part, there has been presented the process that is the symbolic inverse of the "power unto sickness" processes but determined by them - "sickness unto power". It shows the "power" itself to be deviant, transgressing formal limits, exposes the consequences and cracks of its exercise. Here, the third process in psychiatric hospitals of the Lithuanian SSR has, "parallelisation", has been described in which the modern hospital, alongside its formal therapeutic function, acquired parallel, nonformal functions. Description of three of those has been provided: the use of psychiatry (institution) for the purposes of the political regime; its use for the personal purposes of an individual seeking to influence another individual; and its use by individuals on themselves in order to achieve their personal interests.

\section{Power unto Sickness I: Building Addiction to Institution}

In Lithuania of the late 1930s, before the first Soviet occupation, mental patients were treated in two relatively small psychiatric hospitals, also in separate wards of Jewish hospitals, while some would be accepted to care homes for the elderly and children, shelters of the Society of St. Vincent de Paul, or taken care by family members for a little money from municipalities. Consequently, many people with mental conditions would remain outside institutional care, while the state played but a small role in psychiatry. That role would have probably expanded even if Lithuania had remained an independent country, and expansion of psychiatric institutions run by the state would have been observed. Some young-generation psychiatrists were campaigning for change in that direction. Still, the Soviet occupation was what ushered in a radical involvement of the state in psychiatry. Institutionalisation is not the same as statisation of a psychiatric system, as networks of private psychiatric institutions were functioning, for example, in Western Europe or the United States of America; but in the case of Lithuania occupied by the Soviets, the statisation of the psychiatric system first of all meant a rapid and extensive institutionalisation of psychiatry. 
This institutionalisation in Soviet Lithuania was conditioned by not only the regime's effort to install the Soviet healthcare system in the newly occupied lands, but also political decisions on the all-union level. Following deliberations in the Ministry of Health of the USSR in 1949, the authorities concluded that psychiatry was the most problematic of all healthcare areas. ${ }^{3}$ To rectify the situation, a decision was made typical of a state seeking all-encompassing centralized control: not to question the use and sense of psychiatric hospitals, but to build many more and add 50 percent more beds for stationary care. ${ }^{4}$ Moreover, in November 1949, the minister of health of the USSR signed an order to reorganise the entire system of Soviet hospitals and dispensaries. There were to be three types of psychiatric institutions under the new system: psychoneurological hospitals, psychoneurological dispensaries and psychiatric colonies. ${ }^{5}$

The institutionalisation programme of 1949 was implemented gradually. In 1952, the number of beds in Soviet psychiatric hospitals reached the pre-war level (81.2 k) and continued to grow (205.2 $\mathrm{k}$ in 1965; $334.3 \mathrm{k}$ in 1985) at a faster pace than the population. This shows real institutionalisation, i.e., the stationary, institutional psychiatric system was expanding. ${ }^{6}$ This process in the Soviet Union coincided with opposite developments in the West, where critique of institutional psychiatry was pushing deinstitutionalisation. For example, in the early 1950s, Great Britain had eight times more psychiatric beds per capita than the USSR. In subsequent years, however, Great Britain and other countries started closing or scaling down psychiatric hospitals, so the number of beds fell. Meanwhile, the USSR moved in the opposite direction of greater institutionalisation. In the early 1980s, the number of beds per capita in Great Britain and the USSR converged. ${ }^{7}$

3 Benjamin Zajicek, Scientific Psychiatry in Stalin's Soviet Union: The Politics of Modern Medicine and the Struggle to Define 'Pavlovian' Psychiatry, 1939-1953: A Dissertation (Chicago: The University of Chicago, 2009), 106-107.

4 Ibid., 107-108.

5 Ibid., 225.

6 Paul Calloway, Soviet and Western Psychiatry: A Comparative Study (Keighley: The Moor Press, 1992), 45. Also cf., Vasilii Iastrebov, "Organizaciia psikhiatricheskoi pomoshchi” (Eng. Organisation of mental health care) in Obshchaia psikhiatriia, red. Aleksandr Tiganov (Moskva, 2006), http://psychiatry.ru/lib/53/book/28/ chapter/101.

7 Paul Calloway, Soviet and Western Psychiatry, 64. 
On the all-union level, institutionalisation was expanding at a relatively slow pace and never reached the indicators seen in the West before the onset of deinstitutionalisation. In Soviet-occupied Lithuania, however, the extent of institutionalisation was much greater. While there were but two psychiatric hospitals in the 1940s, there were six by the end of the 1950s. Conversely, the number of psychiatric hospital beds grew significantly from 380 in 1945 to 3,425 in $1960 .^{8}$ In later years, three more psychiatric hospitals were opened, and one was closed. Over the five decades of Soviet occupation, Lithuania developed and consolidated an institutionalised psychiatric system centred around hospitals. On the all-union scale, these changes were small and insignificant, but for the Lithuanian SSR they meant an entirely new psychiatric system. This institutionalisation should be seen as a direct outcome of the Soviet occupation. Before the war, psychiatry in Lithuania had been strongly influenced by Western (particularly German) schools, which would have likely exposed the country to the waves of institutional psychiatry critique and deinstitutionalisation even before it could build up an extensive hospital network.

It is important to bear in mind the extent and effects of this institutionalisation, especially since the Soviet authorities presented the system of psychoneurological dispensaries, developed in parallel, as non-stationary help. This was to give the impression that the Soviet psychiatric system was moving towards a more non-stationary care. But this formal opposition between stationary and non-stationary treatment obscures the actual functioning of the Soviet institutional system. Psychoneurological dispensaries were more than providers of therapy for people who voluntarily sought psychiatric help - they screened potential patients, included them into registries and subsequently monitored them. This carried clear political implications. Data in the registries were used by the KGB and the militsiya, while individuals on the lists and those deemed "socially disruptive" could in sensitive circumstances (e.g., before big holidays with demonstrations) be hospitalised, i.e., isolated. These activities of screening the society, selecting the "sick" and expanding the circle of monitored patients intensified particularly in the mid-1960s. It was hardly an accident - the extensive dispensarisation of the society picked up pace the moment that the construction of

8 Leonardas Gargasas, ed., Sveikatos apsauga Tarybų Lietuvoje: Statistinis žinynas (Vilnius: Respublikinis mokslinis-metodinis sanitarinès statistikos biuras, 1961), 53-54. 
new psychiatric hospitals decreased. If we define institutionalisation so as to include not just the individual's isolation from the community, but also loss of the possibility to control their own life or make decisions, subjection to institutional rules, then dispensaries fall under a modified version of institutionalisation, which endures even without hospitalisation. In other words, the dispensary system was entrusted with a task that hospitals could not fulfil - to take account of and control as many socially deviant individuals as possible. More than an alternative to stationary treatment, this system functioned as its supplement. The metaphor of an octopus is quite apt here: the tentacles of dispensaries maintained a grip on non-stationary patients and kept them close to, rather than away from, hospitals so that they could be hospitalised at any given moment.

The growing need for psychiatric hospitals and dispensaries - that is, for institutionalisation - was explained by the Soviet authorities simply enough: the growing number of people with mental conditions. Indeed, the population of Lithuania was growing and overloads in psychiatric hospitals were a constant, albeit fluctuating, problem throughout the Soviet period, i.e., there were always more patients than hospital beds. Vilnius Psychiatric Hospital, for instance, had 80 more patients than available beds at the end of 1961 and 70 more patients than beds at the end of 1972 and 1981. Two or three people would have to share one bed, sleep on folding beds or mattresses in hospital corridors.

The problem of patient overload was not fully solved by either building more hospitals or shortening hospitalisation and moving some chronic patients who had spent 20 or 25 years in hospital to purpose-built homes. So the general institutionalisation of Soviet psychiatry in Lithuania and institutional control over the society exercised through dispensaries suggest that there was some addiction to institutions: dealing with mental health was entrusted to state institutions - hospitals and dispensaries - that had to cover as much of society as possible. A growing population necessitated more hospitals which, in turn, led to more hospitalised patients. The government's response to complaints is a good illustration of institution addiction. Each time the Health Ministry of the Lithuanian SSR received a complaint about patient overload in one hospital or another, the response was the same: we are aware of the situation; unfortunately, there is nothing we can do at the moment, but there are plans to build more psychiatric hospitals. ${ }^{9}$

${ }^{9}$ Lithuanian Central State Archive (hereinafter LCSA), R-769-1-3747, 98. 
Not until the mid-1980s did the authorities take any action to diminish this addiction to institutionalised psychiatric help. Home care of mental patients did exist but was rather marginal and never became a true and systematic alternative to institutional care. Institutionalised psychiatry was not able to deal with its own institutionalisation. However, it could not offer any alternatives to itself, since the unquestioned foundation of the system was statisation, the monopoly of the state. This institution addiction led to the paradox: the institution could be formally strong (present itself as the only solution to the problem) only by being informally weak (admitting indirectly that the problem was unsolvable).

The growing number of hospitalised patients was also predicated on the model adopted by the Soviet psychiatry (see below) which used broader definitions of some mental diseases (schizophrenia in particular) than other countries. Treatments suggested by this model were geared towards stationary therapy (e.g., insulin shock, electroconvulsive therapy, etc.). Secondary factors of institutionalisation also had an effect on the number of patients in psychiatric hospitals. Hospitals were trying to shed their inherited function as asylums (in cases where this was their only function), but they continued to function as shelters where chronic patients would spend years and years of their lives. In 1950, for instance, a medical report from one psychiatric hospital indicated that it admitted many chronically ill patients that year whose relatives never came to pick them up. There was no possibility to discharge them, since they could not be taken to their place of residence. Moreover, some patients arrived without documents, they were picked up from the street, a train or brought in by the militsiya. ${ }^{10}$ The stigmatisation of mental patients was another obstacle to developing alternative care, specialists would say it was very hard to find paid carers for chronic patients. ${ }^{11}$

Finally, an important factor was that, in the second half of the twentieth century, the Lithuanian society was going through the Soviet version of modernisation in which medicalisation (internalisation of the medical discourse) and the growing recognition and acceptance of psychiatry as a branch of medicine were some of the consequences. People were increasingly seeing various mental disorders as "diseases" that could be treated; in the absence of any alternatives, institutional therapy, promoted by the state, was the only option. Therefore, the dynamics of patient numbers

\footnotetext{
10 LCSA, R-505-1-23, 10-11.

11 LCSA, R-505-1-148a, 27.
} 
and addiction to institution should be seen not only in the light of the functioning of psychiatric institutions, but also in the broader context of Soviet psychiatry and social development. In a sense, not just the system itself was addicted to institution, so were individual members of the society: they would jump at the opportunity to hand over a mentally sick person - and the responsibility - to an institution.

\section{Power unto Sickness II: between Moscowisation and Leningradisation}

The sovietisation of psychiatry in Lithuania meant more than merely installing the Soviet healthcare model and the institutionalisation it led to. Incorporated into the Soviet psychiatry system, Lithuania had to abide by its theoretical and practical principles. Lithuanian psychiatrists were also cut off from cooperation with their peers in Western Europe, the ties they had developed before the war. However, speaking about "the Soviet model of psychiatry", particularly in the singular, is problematic. It would seem that, in its ambition to build an anti-capitalist world or even a Bolshevik civilization $^{12}$, the Soviet regime had to come up with its own Marxist-Leninist model of psychiatry with an approach to mental disease and therapeutical practices essentially different from those of the capitalist world. This assumption leads to a question which is the inevitable point of departure for a discussion of the Soviet model of psychiatry whether there was a "communist psychiatry" with its own distinctive features. ${ }^{13}$

Soviet psychiatry is, first and foremost, associated with the name of Ivan Pavlov, a well-known physiologist. However, if we are to properly analyse its foundations, another, even older psychiatric tradition, the German paradigm that established itself in the second half of the nineteenth century, must not be overlooked. It focused on neurobiology and genetics of mental diseases. Its best-known practitioner Emil Kraepelin proposed a diagnostic classification that came to be accepted in psychiatry: he divided psychosis into "dementia praecox" (which would later be known as schizophrenia) and "manic depression". In the early twentieth century, there appeared a strong

12 Stephen Kotkin, Magnetic Mountain: Stalinism as a Civilization (Berkeley: University of California Press, 1995).

13 Greg Eghigian, "Was There a Communist Psychiatry? Politics and East German Psychiatric Care, 1945-1989," Harvard Review of Psychiatry 10, No. 6 (2002): 364. 
alternative to this paradigm, Sigmund Freud's psychoanalysis; however, the biomedical approach came to dominate in many Western countries. This approach looked for biological and organic sources of mental disorders, mostly in the functioning and pathologies of the brain and nervous system. Search for treatments would draw on discoveries in microbiology, biochemistry, genetics and related sciences.

Adherents of the biomedical model would enthusiastically welcome new treatments and often tried to adopt them rather hurriedly. One of such methods was convulsive therapy, developed in the 1930s, which used insulin-induced coma, cardiazol and electricity ${ }^{14}$ to induce shock with possible epileptic seizures in patients. Although sometimes met with scepticism, these treatments quickly spread across the world, which had probably less to do with their effectiveness than the desperate need for "real" treatment methods felt in the psychiatric community for years. Lithuania was no exception. In Kaunas, the capital city then, insulin coma therapy was first adopted in 1934, cardiozol shock in 1936, while electroshock therapy was first used in Vilnius Psychiatric Hospital in 1940. ${ }^{15}$ This shows that, even before the Soviet occupation, Lithuanian psychiatrists had a clear preference for the Kraepelian paradigm and its therapeutic methods.

The Kraepelian paradigm also informed Soviet psychiatry. Between the wars, Soviet psychiatrists would communicate with their colleagues in Germany and Western Europe ${ }^{16}$ and, despite the communist ideological framework, there was a considerable variety of psychiatric ideas and practices in the Soviet Union in the first post-revolutionary decade ${ }^{17}$. Only in the 1930s did the Soviet authorities start finding this variety problematic. Under Stalinism, there was a need for an ideological canon in psychiatry, as in other domains. Physiologists' works on the brain and nervous system, informed by scientific positivism and materialism, were of some use for

14 Richard Abrams, Electroconvulsive Therapy (Oxford: Oxford University Press, 1988), 3-6.

15 Viktoras Vaičiūnas, "Psichinių ligonių gydymas", Lietuviškoji medicina, No. 1-2 (1943): 11-14. Apparently, following the occupation Lithuania was the first Soviet republic to use electroshock. Cf. Aleksandr Ilich Nelson, Elektrosudorozhnaia terapiia v psikhiatrii, narkologii i nevrologii (Moskva: Binom, 2005), 23.

16 Grégory Dufaud, Lara Rzesnitzek, "Soviet Psychiatry through the Prism of Circulation: The Case of Outpatient Psychiatry in the Interwar Period," Kritika: Explorations in Russian and Eurasian History 17, No. 4 (2016): 781-803.

17 Benjamin Zajicek, Scientific Psychiatry in Stalin's Soviet Union, 1-2. 
that. In its post-war quest for the centralised vertical axis of government, the Soviet regime used Pavlov's theory to homogenise and ideologically purify Soviet psychiatry. Political and ideological pressures on medicine, as well as on other scientific and cultural fields, intensified in particular in the wake of the campaign against "rootless cosmopolitanism" and "subservience to the West" of the late 1940s. In the medical field, the campaign culminated with the so-called Pavlovian session, a joint conference of the USSR Academy of Sciences and the USSR Academy of Medical Sciences in the summer of 1950. The session proclaimed Pavlov's physiological theory the only truly Soviet approach, while all the alternative interpretations were condemned. ${ }^{18}$ One year later, Soviet psychiatrists organized their own Pavlovian session. They, too, were instructed by the authorities to follow Pavlovian physiology. In other words, Pavlov's theory was turned into a medical dogma. ${ }^{19}$

Pavlov's physiological approach to human psyche was acceptable to the Soviet ideology for two main reasons: it could be said to be scientifically provable (through experiment) and relied on the materialist conception of the human being, i.e., rejected the soul (spirit, thoughts) and body (matter) dualism. Pavlov's teachings about conditional and non-conditional reflexes were seen as echoing dialectical materialism in physiological sciences. Soviet psychiatry was contrasted with the so-called idealist philosophy and categorically dissociated from psychoanalysis, John B. Watson's behaviourism and other Western theories that were deemed idealist. Mental disorders were unambiguously linked to biological processes in the brain. Despite the breadth of possible interpretations of Pavlov's teachings, Soviet ideologues thus channelled them in the way that fit their purposes. The Soviet Pavlovian dogma was compatible with biomedically-oriented therapies. The functioning of the nervous system was understood in terms of balancing stimulation and suppression, with mental disorder resulting from this balance being upset. Convulsive therapy, and later medication, was used to effect stimulation or suppression. On the other hand, the social and cultural dimension could not be completely eliminated either, since the Soviet psychiatric approach saw the human brain as a necessary, but insufficient

18 Ethan Pollock, Stalin and the Soviet Science Wars (Princeton, Oxford: Princeton University Press, 2006), 136.

19 Sidney Bloch, Peter Reddaway, Russia's Political Hospitals: The Abuse of Psychiatry in the Soviet Union (London: Gollancz, 1977), 40. 
explanation for mental processes. ${ }^{20}$ External social and cultural environment had to be accounted for, too. This approach, however, only took heed of a person's relation with the external environment, the emotional or psychological atmosphere, but not their inner experiences.

To be sure, practical application of the Pavlovian dogma got exhausted soon enough. In Lithuanian psychiatric hospitals, for instance, talks about instilling Pavlov's teachings into medical practices (formally or actually) lasted until about 1954. In a broader sense, however, this dogma determined the direction of entire Soviet psychiatry. It significantly restricted alternative development opportunities (it gradually became clear that these could not be entirely eliminated), dictated particular therapeutic principles (stimulation/suppression) and set the trajectory of the biomedical model as the base. This way, Pavlov's teachings, even though considered a branch of behaviourism, led to the entrenchment of the Kraepelian paradigm thanks to their physiological materialist underpinnings.

Soviet psychiatry was therefore built on rather strict and ideologically mandated terms. Within this framework, however, there existed theoretical and practical variances and disagreements among psychiatric schools from different republics or cities. The two main schools of Soviet psychiatry were developed in Moscow and Leningrad.

The researcher Paul Calloway describes them in terms of two key theoretical differences ${ }^{21}$ :

(1) A search for external factors in the aetiology of mental disease. Though this was a common feature of all the variants within Soviet psychiatry, it was more readily associated with the Leningrad school. The Moscow school attributed more significance to endogenic processes and psychopathology, while the Leningrad school focused on physical environmental factors. To explain schizophrenia, for instance, the latter would look for viral causes.

(2) The Leningrad school emphasised psychosocial aspects of mental disorders more than the Moscow school. The Leningrad school adherents would focus on external psychosocial factors not only in their search for the causes of the disease, but also in treating the patient. The Bekhterev Institute in Leningrad was more active in developing theories for psychotherapy and rehabilitation.

20 Paul Calloway, Soviet and Western Psychiatry, 2.

21 Ibid., 12. 
Meanwhile, the Moscow school tended to focus on diagnosis, classification and psychopathology as well as abnormalities in biological development.

One psychotherapist, who worked in the Soviet period and studied in Leningrad, summarised the differences thus: the Moscow school was more "psychiatricised", while the Leningrad school was more "psychotherapeuticised". 22 In this sense, "psychiatricised" meant a more conservative interpretation of biomedical psychiatry with its practical implications: stricter focus on biological causes of the disease and active methods of treatment, primarily with medication. "Psychotherapeuticised" meant a more liberal interpretation of the same model, more open to aetiological theories and therapeutic methods adopted from other psychiatric models, i.e., attaching more significance to social and psychological factors. These differences and competition between the two most influential schools of psychiatry could have concrete practical consequences for, say, diagnosing schizophrenia. When the Pavlovian dogma took hold of Soviet psychiatry in the early 1950s, this boosted the role of the Muscovite psychiatrist Andrei Snezhnevsky. He is best known for proposing a very broad definition of schizophrenia and coining the term "sluggish schizophrenia", which allowed for a rather loose interpretation of schizophrenic symptoms. The Leningrad school would not accept this conception, preferring a much narrower definition of schizophrenia. The Russian dissident Vladimir Bukovsky recalled that he was diagnosed with "sluggish schizophrenia" in Moscow, but when he went to Leningrad, professor Izmail Sluchevsky, then the head of the Bekhterev Institute, immediately changed the diagnosis, because he simply refused to accept "sluggish schizophrenia" as such: "He'd say, this is not psychiatry, it's rubbish." ${ }^{23}$ Archival sources confirm this. Dr. Kovaliova, who returned from Leningrad to Vilnius in early 1966, said she attended professor Sluchevsky's lectures on psychiatry. She observed: "Here, we diagnose schizophrenia more often, whereas similar cases in Leningrad are diagnosed as infectious psychosis, especially rheumatism." ${ }^{24}$ According to some authors, the Bekhterev Institute was eventually forced to accept "sluggish schizophrenia" after Sluchevsky's death in

22 Interview with Kristina Ona Polukordienė, 12 December 2014.

23 Interview with Vladimir Bukovsky, 28 November 2013. Also cf. Vladimir Bukovsky, To Build a Castle: My Life as a Dissenter (London: Andre Deutsch, 1978), 215.

24 LCSA, R-505-1-178, 1. 
$1966^{25}$, but the psychiatrists I interviewed claimed that diagnostic interpretations continued to be widely different. ${ }^{26}$

The two Soviet schools also differed in their approach to psychotherapy. At one point, this therapeutic method was making inroads into Soviet psychiatry and the Moscow school did not outright reject it. However, in informants' experience, the Muscovites had a rather different understanding of psychotherapy:

"Perhaps the only thing that I saw [..] was the famous Section Nine of the Bekhterev Institute in Leningrad that was truly a beacon for us. [..] There was a group that was following Western trends. They already had methods not from the directives - for example, group psychotherapy sessions, I attended them for several months. [..] In Moscow [..] what psychotherapy can you speak of, there was none, only those things straight from the directives." 27

This remark points at the final key feature of the Leningrad school - its relative openness to ideas from the West, including processes in psychiatry. Granted, those ideas always had to be ideologically adapted to the Soviet psychiatric discourse.

In addition to competing with one another for weight and status (though Moscow did enjoy an upper hand), the two Soviet psychiatry schools were able to exert different kinds of influence on Soviet republics, on cities with psychiatric hospitals or education centres, or even on individual hospitals.

At least in terms of therapeutic practices, there was no significant variation within Lithuanian psychiatry until the 1960s. Everything was based almost exclusively on the biomedical model. Convulsive therapy was dominant up until the mid-1950s, with insulin therapy and electroshock the most popular treatments. In later years, with the onset of the so-called era of modern psychopharmacology ${ }^{28}$, medications took over dominance, first and foremost the Soviet-made "native" version of chlorpromazine, aminazine. At this point, much like in other countries, Soviet

25 Sidney Bloch, Peter Reddaway, Russia’s Political Hospitals, 222.

26 Interview with Kristina Ona Polukordienè, 12 December 2014.

27 Interview with Danute Gailienè, 22 January 2014.

28 Ville Lehtinen et al., "Developments in the Treatment of Mental Disorders" in Mental Health Policy and Practice across Europe: The Future Direction of Mental Health Care, ed. Martin Knapp et al. (Maidenhead: Open University Press, 2007), 130. 
psychiatry underwent a fundamental transformation in terms of therapy. Although in terms of the psychiatric model, the use of medication merely extended the dominance of biomedical psychiatry. Only now biological processes in the brain and nervous system would be manipulated with chemical substances. This was one of the reasons for such an easy and enthusiastic transition from one stage of therapy to the next - medication did not undermine the dominant conception of Soviet psychiatry, but helped entrench it.

However, we can discern new processes in the later 1960s marking changes in the theoretical and practical model cultivated in the Lithuanian SSR. Comparing Soviet and Western psychiatry, Calloway argues that psychiatrists with the "western" orientation were more amenable to using electroconvulsive therapy, therefore it was more popular in Leningrad and the Baltic countries than in Moscow and other Soviet republics. ${ }^{29}$ However, variations existed within as well as between Soviet republics. In the Lithuanian SSR, this is best exemplified by two institutions that were located nine kilometres apart: the psychiatric hospitals of Vilnius and Naujoji Vilnia. The latter was set up in the early 1960s as a department of the Vilnius hospital, but was soon reorganised into an autonomous institution, grew rapidly and eventually reached the size and the weight to become the centre of Lithuania's psychiatric system. Subsequently these two hospitals competed for influence for almost three decades. Their separation half-accidentally and half-logically coincided with the differences in interpretation observed in the Soviet model of psychiatry as a whole: Vilnius Psychiatric Hospital was gravitating towards the Leningrad school, while Naujoji Vilnia was leaning towards Moscow. The former, we might say, was subject to Leningradisation, while the latter, to Moscowisation.

After 1965, several kinds of Leningradisation processes could be observed at Vilnius Psychiatric Hospital, encompassing not only changes in therapy in the narrow sense, but also shifting attitudes to mental diseases, mental patients and psychiatric hospitals. First and foremost, the Vilnius hospital embraced psychotherapy and psychology rather rapidly, expanding their practical application. Vilnius psychiatrists were the most active champions of psychotherapeutic ideas. The hospital's dispensary had a psychotherapy room. It was here, of all the psychiatric institutions in

29 Paul Calloway, Soviet and Western Psychiatry, 90. 
the Lithuanian SSR, that the first full-time position for a psychologist was set up in 1974 and group psychotherapy was introduced soon afterwards. According to some psychotherapists, Vilnius was the "centre of psychotherapeutic knowledge" for the entire Soviet Union and its seminars attracted specialists from other Soviet republics. ${ }^{30}$

By the mid-1960s, there was a talk of even greater novelties in Vilnius Psychiatric Hospital: a freer regime (possibilities for patients to move more freely, spend time at home, etc.) and a greater role for non-stationary care. In doctors' discussions, these changes were associated with the Leningrad example. In fact, they reflected even wider currents - Soviet psychiatry inevitably had to react to developments in the West where psychiatry geared towards stationary treatment had been under harsh criticism for about a decade. Minutes from internal meetings show that echoes of this criticism would reach the professional psychiatric community and spark closed discussions. ${ }^{31}$ Liberalisation in the Vilnius hospital was slow, but it was happening - until the decision came in the 1980s to radically transform things and introduce the so-called four regime system. It allowed for a semi-stationary treatment. Accounts from doctors who had spent time in Leningrad contributed to the transformation ${ }^{32}$. In other words, these decisions that could be interpreted as the first steps toward deinstitutionalisation were also a result of Leningradisation (in the mid-1980s, the very first "day stationary", where patients were kept only during the day, was established in the Vilnius hospital).

These processes geared towards psychological and sociocultural psychiatry remained rather marginal vis-a-vis biomedical therapy, but they nonetheless marked significant transformations in Soviet Lithuanian psychiatry. This is particularly clear when compared to the situation in Naujoji Vilnia Psychiatric Hospital. Similar processes did influence this institution, too, but the changes there were much more modest and slow and, in some aspects, there were none at all. Medication-based treatments, deriving from the biomedical model, remained more popular, while alternatives would be met with more scepticism. Conditions for patients in this hospital also remained stricter.

\footnotetext{
30 Danguolè Andrijauskaitè, "Psichoterapijos raida Lietuvoje", Gydymo menas, No. 12 (2004): 82 .

31 LCSA, R-505-1-195, 26r-27v.

32 LCSA, R-505-1-383, 84v.
} 
When it comes to describing the psychiatric model used in the Lithuanian SSR, it can be claimed that, on the one hand, despite different explanations and conceptions of disease aetiology, therapeutic methods were similar or even identical to most used in Western countries (one or two exceptions notwithstanding), only the intensity of their application varied. On the other hand, Soviet ideology (via the Pavlovian campaign) limited the scope and direction of therapeutic options. Therefore, it can be said that the therapeutic model that developed here was Soviet-specific, but not original. The basis for patient treatment in Soviet Lithuanian psychiatry was - and remained throughout the Soviet period - the biomedical model, which was predicated on the Kraepelian paradigm adapted to the Pavlovian therapeutic logic; this paradigm, recall, had been favoured by Lithuanian psychiatrists even before the Soviet occupation. This at least in part explains why some therapeutic methods derived from the biomedical model could have been used even more intensely here than in Moscow. True, Moscow was the all-union centre of psychiatry, dictating the disease classification and basic therapeutic principles that were compulsory throughout the USSR. Hospitals in the Lithuanian SSR could not but submit to its dictates, which led to inevitable Moscowisation. However, shifts in therapy that emerged in the mid-1960s and differences in extent to which they were adopted in individual hospitals, suggest that either Leningrad or Moscow could have a bigger influence on any given hospital. In cases where Leningradisation prevailed, it meant neither relinquishing the biomedical model, nor completely escaping Moscow's influence - rather, it complemented, and at times adjusted, this model with assimilated elements of psychology and sociocultural psychiatry. Additionally, Leningradisation describes a therapeutic model that was potentially more open to influences of Western ideas, albeit indirectly through politically filtered and ideologically adapted Soviet versions of these ideas. Just like aminazine was the "native" version of Westerninvented chlorpromazine, so Leningradised therapy was the "native" version of psychological and sociocultural ideas that did not change nor even threaten the dominance of the biomedical model. Meanwhile hospitals under Moscowisation took a more conservative approach to new psychological and sociocultural methods of therapy and were less affected by refracted Western ideas - but could (at least in the case of Naujoji Vilnia Hospital) accrue more local power. 
The processes of Leningradisation and Moscowisation point to the presence of relative diversity and choice (limited though it was) within the Soviet system of psychiatry. Algirdas Dembinskas, who worked as a psychiatrist at Vilnius Psychiatric Hospital, says that each doctor could individually pick between the Moscow and the Leningrad schools, while only the younger generations of psychiatrists showed consistent preference for Leningrad. ${ }^{33}$ It was the earlier 1960s that saw the generational shift at Vilnius Psychiatric Hospital. As some older doctors were retiring, others followed Jochel Gliauberzon, the older-generation psychiatrist who had headed the hospital, to Naujoji Vilnia and were gradually replaced by the young. Jurgis Sargautis, who took over the hospital's management, continually declared ambitions to use "the latest methods". One psychiatrist described the differences in Gliauberzon's and Sargautis' approaches: "I was really lucky that the hospital's chief doctor Sargautis was favourable to psychotherapy and supported me." 34 However, the Vilnius hospital's orientation towards Leningrad probably had other reasons, too: the hospital's close and long-lasting cooperation with Vilnius University encouraged broader scientific interests, a stronger intellectual potential and greater openness to novelties. Personal connections forged during study trips to Leningrad would also attract more guest doctors from this city. One former director of Vilnius Psychiatric Hospital said that Leningradians almost always picked to give lectures in this hospital, while Muscovites preferred Naujoji Vilnia. ${ }^{35}$

\section{Sickness unto Power: \\ Parallelisation}

The Soviet psychiatric hospital was an essentially modern institution because, first and foremost, it had a clearly and unambiguously defined function and responsibility - to administer therapy. From the late 1960s at the latest, however, there emerged a process whereby the psychiatric hospital was pulled into the world of informal relations that developed during

33 Interview with Algirdas Dembinskas, 12 February 2015.

34 Arūnas Peškaitis, Andrius Navickas, red., Gyvename karta, bet kiekviena dieną: pokalbiai su gydytoju psichiatru-psichoterapeutu Aleksandru Alekseičiku (Vilnius: Bernardinai.1t, 2012), 56.

35 Interview with Raimundas Milašiūnas, 3 March 2015. 
the Soviet period (blat, corruption, parallel economy, etc.). This process could be termed parallelisation: in addition to its main therapeutic function, the psychiatric hospital took on para-therapeutic - i.e., unrelated to therapy, but existing under its cover - functions. The chronology of this process delineated below was suggested by the sources, though it is possible that the phenomena described could to a greater or lesser extent have been discernible in earlier periods as well, which is difficult to trace now; witnesses who can give their accounts today only came into contact with psychiatry in the late Soviet period.

The multi-layered and complex process of parallelisation were involved and exploited by both the state and the society. The psychiatric hospital was a launching pad for political, social and personal interests and needs. It was part of the general sociocultural space of the Soviet era and therefore included informal practices characteristic of other fields (say, the role of blat in getting admitted to a hospital, being assigned a room or a doctor). Below, I will highlight and shortly describe features of parallelisation specific to psychiatric institution.

1. Political abuse. Central to parallelisation was utilising psychiatry for the political purposes of the Soviet regime: to discredit its opponents and critics and/or isolate them in hospitals after declaring them mentally ill. Historical accounts of the political abuse of psychiatry in the Soviet Union usually begin with the 1950s (although some mention earlier instances) when the launch of destalinisation gave a silent promise to the society (without making it explicit) that massive and reckless political repressions would not return. There was an effort to lend the regime an air of legality, while Nikita Khrushchev publicly proclaimed that there were no political prisoners in the Soviet Union and everyone was happy with socialismin-construction ${ }^{36}$. In this environment of relative political change the Thaw - there soon emerged a dissident movement that would openly declaim the state of human rights in the Soviet Union and call for reform ${ }^{37}$. The tension between ideological declarations and reality forced the regime to look for ways out - and one of them was using psychiatry against the opposition (although targeted repressions were in no way retired).

\footnotetext{
36 Vladimir Bukovsky, To Build a Castle, 195.

37 Liudmila Alekseeva, Istoriia inakomysliia v SSSR: noveishii period, 3 ed. (Moskva: Mosk. Helsink. gruppa, 2012), 208-216.
} 
The political abuse of psychiatry in the Soviet Union has been meticulously documented and researched. ${ }^{38}$ For the purpose of the article, analysing the relation between centre and periphery, it is worth noting but one thing: in the Lithuanian SSR, there have been only a handful - or about a dozen at most - cases of clear and proven abuse of psychiatry for political purposes. Compared to the Russian SFSR, it would seem, this method of political repression was used in Lithuania rather sporadically, perhaps in exceptional cases only. It could be a matter of historiography (Lithuanian historians have researched this specific topic very little) or sources (institutions in charge of personal data protection refused to give me access to personal medical histories that would have allowed me to analyse motivations for "hospitalisation"). On the other hand, one should consider the possibility that the Soviet authorities simply used this method of repression much more widely in Russia than in peripheral republics, at least Soviet Lithuania. Several factors could be at play. ${ }^{39}$ First, psychiatry could have been a more useful tool against dissidence than resistance, since dissidents demanded certain rights and sought to reform the system (that is to say, formally acted within Soviet law and often used Marxism-Leninism to back their arguments), while resistants fought against the system (that is, engaged in anti-Soviet activities, a grave crime from the point of view of Soviet law). Thus, there was less of a formal basis to punish dissidents, possibly forcing the government to look for alternative sanctions. The activities of organisations and groups opposing the regime in the Lithuanian SSR were often more characteristic of resistance than dissidence (although there existed, for example, a Helsinki Group). This line of reasoning could also be supported by the fact that in 1956, during the Thaw, the KGB asked for an increase in its recently downsised staff in the Lithuanian SSR and used traditional methods of repression against the local resistance rather

38 E. g., Sidney Bloch, Peter Reddaway, Russia's Political Hospitals; Sidney Bloch, Peter Reddaway, Soviet Psychiatric Abuse - The Shadow over World Psychiatry (London: Gollancz, 1984); Harvey Fireside, Soviet Psychoprisons (New York, London: W. W. Norton \& Company, 1979); Anatolii Stefanovich Prokopenko, Bezumnaia psikhiatriia: sekretnye materialy o primenenii v SSSR psikhiatrii v karatelnykh tselkh (Moskva: Sovershenno sekretno, 1997); Rebecca Reich, "Inside the Psychiatric Word: Diagnosis and Self-Definition in the Late Soviet Period," Slavic Review 73, No. 3 (2014).

39 I am grateful to two of my colleagues from the History Faculty of Vilnius University, Dr. Valdemaras Klumbys and Dr. Marius Émužis, for invaluable comments on this issue. 
extensively. Moreover, the reason for using psychiatry rather than traditional repression could have been the Soviet government's reluctance to give its opponents (especially the better-known ones) a trial, since this could have occasioned symbolic manifestations of opposition (e.g., supporters of the defendant rallying outside the courthouse). These manifestations, however nominal, would have been more problematic in Moscow or Leningrad, with these cities' foreign press corps, than in Soviet Lithuania (where the authorities would try dissidents from other republics, too, like Sergey Kovalev). Finally, a decision to hospitalise a person involved an "expert" (though not voluntary) role played by doctors. One could assume that the KGB had much older and deeper connections with at least some psychiatric institutions in the Russian SFSR than in the Lithuanian SSR and so had more levers to pressure psychiatrists.

2. Violence through institution. The psychiatric hospital could be a tool for isolating, discrediting and restricting the rights of someone for personal, as well as political, purposes, i.e., a tool for furthering one's personal interests in conflict situations. Such abuse was not sanctioned by the political power and was officially deemed a crime, but in a way it replicated the government's actions on a personal level. This was possible only in the informal space that emerged in the Soviet period and enabled illegal or semi-legal agreements, relations based on personal connections and widespread abuses of office. The government had established rather broad legal criteria for involuntary treatment, setting an example of how one could manipulate mental diagnoses and restrict a person's will. In one instance, a medical emergency team accompanied by the police came to a man's home in January 1987. Despite his incredulous protestations, they took the man to Žiegždriai Psychiatric Hospital. He was examined by doctors who quickly concluded that the man was completely sane and released him the following day. The unfortunate victim of forced hospitalisation reckoned that the whole incident was set off by his former wife against whom he was to give testimony in a court of law. ${ }^{40}$ A commission appointed by the Health Ministry of the Lithuanian SSR investigated his complaint and concluded that a doctor from Žiegždriai Psychiatric Hospital had indeed signed a referral without ever seeing the patient, acting solely on the words of his

40 LCSA, R-769-1-10092, 138. 
former wife. Another doctor also signed the referral without ever seeing the man either. ${ }^{41}$

By the late Soviet period, Soviet citizens had become quite well versed in the informal rules of behaviour and accrued expertise in how to exploit the official system for their personal gain. Wherever the state had created an avenue for itself to interfere into a citizen's personal life and restrict (or take away completely) their autonomy for the sake of actual or purported threats to social security, Soviet citizens would also exploit this avenue for their own personal purposes. In general, this led to greater social insecurity and we could call it person-on-person violence through institution.

Involuntary treatment had to be sanctioned by court, but judgements relied on expert testimonies which, in turn, allowed for possibilities to manipulate diagnoses, if one could reach an agreement with psychiatrists. Psychiatric institutions could be involved in a wide variety of situations where one party to a conflict sought to legally and morally discredit the other, say, in clashes over inheritance: a will could very well be disputed, should its author be ruled incapacitated. Such situation is described in a complaint to the Health Ministry filed in 1984 by a 76-year-old man. The complainant claimed that his son - a doctor and a teacher at Kaunas Institute of Medicine - told another doctor in a local outpatient clinic that his father was violent, had beaten up his wife and posed a threat to her life. This landed the elderly man in Žiegždriai Psychiatric Hospital where he spent a month. According to the complainant, his son did this to dispute a will where he was not included. The commission that investigated the complaint concluded that "examination did not reveal any significant mental disorders" and that "treatment at a psychoneurological room is not needed at this time". ${ }^{42}$

Thus, commonplace practices of the Soviet informal world that emerged in this period morphed into parallelisation actions of an entirely new level in the psychiatric system: violence through institution. Documented cases suggest that it was usually the doctors - involved in corrupt personal ties who would unnecessarily send people to psychiatric hospitals or recognise them mentally unfit without ever seeing them. The extent of such abuse

\footnotetext{
41 LCSA, R-769-1-10092, 132.

42 LCSA, R-769-1-9700, 92-95.
} 
is difficult to gauge, and only such cases are known where victims took action to defend themselves. However, the very existence of such cases shows that it was not only the regime that exploited psychiatry for political purposes, individual members of the Soviet society also instrumentalised psychiatric institutions for violence.

3. Solution to conflict with the state. A site of abuse by the state and individuals (echoing, in a way, the state's actions), the Soviet psychiatric hospital was also an instrument for citizens to resolve their conflicts with the Soviet state, i.e., to evade duties, obligations, prohibitions and criminal prosecution. Many parallelisation actions of this kind are only available through fragments and hints in archival documents and memoirs. For instance, being admitted to a psychiatric hospital or diagnosed with a mental disorder could have been the only way for students to avoid expulsion or get academic leave. Similarly, individuals charged with vagrancy could hope to avoid punishment (or criminals could avoid jail time) and women could be allowed to terminate late pregnancy if they were "mentally unfit". Homosexual men would also shield themselves from criminal prosecution with mental diagnoses. Besides, the prevailing understanding at the time (and not just in the Soviet Union) regarded homosexuality as a treatable, as well as punishable, "deviation". Studies in other countries show that men would oftentimes voluntarily turn to psychiatrists seeking to be "cured" from homosexuality. ${ }^{43}$

Aleksandras Alekseičikas, who worked as a psychiatrist at Vilnius Psychiatric Hospital, claims that he used to protect homosexual men by giving them vague diagnoses: "I would give them this universal diagnosis, 'compulsive neurosis' - well, a man is compulsively attracted to men, not women. I wouldn't, of course, specify the attraction, only that he's drawn to doubts, insecurities, doesn't feel manly enough, all very disguised." 44

Attempts to bypass the state-imposed rules and obligations would sometimes acquire a political meaning. A good example is using psychiatry to dodge service in the Soviet army. This was not a novel or a specifically Soviet phenomenon - there are documented cases of young men simulating mental illness to avoid draft in independent Lithuania before the war.

43 E. g., cf. Tommy Dickinson, 'Curing queers': Mental nurses and their patients, 1935-1974 (Manchester: Manchester University Press, 2014).

44 Interview with Aleksandras Alekseičikas, 8 January 2014. 
However, narratives of this kind are particularly entrenched in memory discourses about the Soviet period, with informants often claiming this to have been the only way not to serve in the military: "[... I knew no other ways how to do it." 45 In fact, the informal Soviet space of corrupt and personal ties did offer alternatives: patronage of influential members of the nomenklatura, friendships with doctors and bribes could help one avoid military service. Simulating a mental disease was, therefore, a recourse for social groups that had no access to alternative methods.

What made psychiatry a useful tool for avoiding military service was its commonly-acknowledged weakness as a medical field: the indefinability and conventionality of mental disease. A diagnosis could not always be backed with somatic symptoms and often relied on a particular psychiatrist's observations and interpretation. In retrospect, however, it is surprising how often men would quote "easy access" to a psychiatric hospital as the reason for using this draft-dodging method, i.e., how successfully they could simulate a disease. ${ }^{46} \mathrm{~A}$ deeper analysis of patients' medical histories would be required to properly explain this ease, but given that they are unavailable, one could raise several hypotheses.

First, there may have developed an implicit cooperative understanding between psychiatrists and "patients". In Lithuania, the Soviet army was a symbol of occupation for a significant part of the population. Moreover, the culture of violence, coercion and humiliation that prevailed in the military was common knowledge, as were the very real threats to life one faced while serving, particularly at times when the Soviet Union was sending troops to war zones (e.g., Afghanistan). The young men themselves and other people (including doctors) could have - and did - regarded military service as less of a civic duty than a life-threatening obligation imposed by a foreign power. In the occupied periphery of the Soviet Union, these political reasons could have played a more significant role in the implicit cooperation between doctors and "patients" than in Russia itself. Some psychiatrists could decide to help the young men without any explicit agreement, just by recognising their simulation. This was a game of mutual simulation: one side would simulate mental disease, while the other would

45 Interview with G. U., 7 February 2014.

46 Interview with E. N., 16 January 2014; Interview with Ž. B., 18 February 2014. 
simulate a diagnosis and the need to hospitalise the "patient". This hypothesis is backed by testimonies from some of the "patients" and doctors themselves.

Second, what made it relatively easy to get into a psychiatric hospital could have been the way Soviet psychiatry conceived of the mental disease. Some definitions were so broad and included symptoms so vague that oftentimes one would not even need to exhibit serious behavioural and cognitive deviations in order to be diagnosed with a mental disease. Eccentric, unusual behaviour at odds with conservative social norms could be a sufficient reason to suspect mental disorder:

"I recall, when I came to Vasaros street [the address and a euphemism for Vilnius Psychiatric Hospital], I had shaved my head and the doctor asked me [..], why did you shave your hair? I said, to see the shape of my head. Well, she said, and how does it look? A brain hemisphere is missing, I said. I was surprised that they started writing something down in the file, take some notes about it. I thought then that perhaps humour is treated as a symptom in this hospital or something." 47

This way, young men would simulate a mental disease, be hospitalised and deemed unfit for military service. At the same time, these practices embodied a separate category of parallelisation in psychiatric hospitals and contributed to transforming them into something more than institutions for therapy.

\section{Conclusions}

In Lithuania, much like in the rest of the Western world, psychiatrisation began in the early years of the twentieth century. Due to historical circumstances, the period of its most intense expansion and entrenchment coincided with the Soviet occupation and its programme for radical transformation of people's lives. This determined the direction and character of the development of psychiatry. The Soviet healthcare system installed in Lithuania after World War Two covered psychiatry, too. Being sick meant being dependent on state institutions. Thus, power unto sickness was power unto man.

${ }^{47}$ Interview with G. U., 7 February 2014. 
Institutionalised - therefore, state-managed - psychiatry was made an instrument of sociopolitical control by the regime. State-run institutions would help identify and supervise a particular segment of the society, the "mental patients". The institutionalised system of psychiatry gave rise to a phenomenon I call addiction to institution: with the expanding number of people diagnosed with mental conditions and in need of psychiatric care, hospitals would constantly be overloaded with patients, but the way this problem was addressed was by building more institutions. The Soviet occupation also meant that Lithuanian psychiatry was pulled into the Soviet psychiatric field, cut off from direct influences from the West and forced to operate under a model imposed from the Soviet centres. However, Soviet psychiatry was far from being one-dimensional. Its multiple centres (Moscow, Leningrad) shaped standards that allowed for some variation within the bounds of one psychiatric model, giving some choice (albeit narrow and rather relative) among competing directions. The sociocultural environment in the Lithuanian SSR and the prewar penchant for the German psychiatric tradition contributed to local specificities of Lithuanian psychiatry. Here, in the periphery of the Soviet Union, these specificities and small variations among individual hospitals developed under a tension between two main influences, Moscowisation and Leningradisation, or the more conservative biomedical therapy and the more liberal psychotherapy. Overall, despite the putative isolation from the Western world, Soviet psychiatry in general and Lithuanian psychiatry particularly were not immune to influences and changes in the West, for example, psychopharmacology and debates about the harm of institutionalisation to patients. Still, new global trends in psychiatry could only come in their "native" - i.e., Sovietised - versions.

The "power unto sickness" built up by the Soviet psychiatric system had an underside. This was embodied in the processes of parallelisation, the expansion of non-therapeutic functions of Soviet psychiatric hospitals. What could appear as the opposite of psychiatrisation was in fact its (by no means inevitable) consequence. The state's power unto sickness - and unto man - came to signify direct political power where psychiatry could be used for political purposes. However, perhaps even more importantly, individual citizens, too, as if imitating the state's actions, would exploit the overgrown practices of the Soviet informal space to further their interests through the (relatively new) institution of psychiatry. Arguably, 
the processes characteristic of Soviet psychiatry in general may have had specific characteristics in peripheral republics. Specifically, the regime was more inclined to deal with political opponents using "traditional" forms of repression rather than psychiatry, while young men seeking to avoid "stateimposed obligations" could have found it easier to make use of psychiatry because of essentially the same political reasons.

The example of Soviet psychiatric hospitals shows how, within the context of psychiatrisation, the Soviet state and its citizens developed their relation with one another. One could perhaps argue that no other Soviet citizen was in a situation so paradoxical than he who was deemed "mentally ill". Even in the country where the state controlled all aspects of citizens' lives, he would find himself in a field of specifically strict control, but at the same time be freer from other aspects of that control, since being "mentally ill" would liberate him from some of the duties, obligations and punishments that "normal citizens" were subject to. This way, control institutions could also be a way to escape control. People, thus, tried to take back power, by exploiting the state's powerlessness, and the history of Soviet Lithuanian psychiatry becomes a story of power unto sickness turning into sickness unto power.

Translated by Justinas Šuliokas

\section{Vara pār slimību, slimība pār varu padomju psihiatrijas perifērijā}

\section{Kopsavilkums}

Trīs svarīgākie procesi psihiatriskajās slimnīcās Lietuvas Padomju Sociālistiskās Republikas (Lietuvas PSR) laikā (1944-1990) tiek analizēti no centra un perifērijas attiecību skatpunkta. Divi no šiem procesiem iemieso tā saukto "varu pār slimību", t. i., padomju valsts centienus ietekmēt cilvēkus, kuru uzvedība nebija pien,emama un kuri tādēl tika uzskatīti par garīgi slimiem. Pirmo procesu var uzskatīt par ārēju - psihiatriskās aprūpes sistēmas institucionalizācija radīja apstākḷus, lai varētu īstenot minēto ietekmi. Šajā gadījumā procesa galvenais rezultāts ir tā sauktā atkarība no iestādes, kur problēmas, kas radušās institucionalizācijas dēḷ, tiek risinātas ar papildu institucionalizāciju. Otrais process ir iekšējs. 
Rakstā analizēts padomju psihiatrijas modelis, ko izmantoja Lietuvas PSR, un aplūkots jautājums, vai ir pastāvējis vienots un unikāls padomju psihiatrijas modelis. Trešais process ir simboliski apgriezts koncepts, pretējs "varai pār slimību" - "slimība pār varu". Tas parāda, ka pati vara nav pieņemama, tā pārkāpj formālās robežas, atklāj tās izpausmju sekas un nepilnības. Trešajā procesā izpaužas paralēlisms - tiek aprakstīta modernā slimnīca, kurā līdztekus tās formālajai ārstniecības funkcijai pastāv neformāla funkcija.

Atslēgvārdi: Lietuvas PSR, Padomju Savienība, psihiatrija, psihiatriskā slimnīca, institucionalizācija, paralēlisms.

\section{Secinājumi}

Līdzīgi kā citviet rietumu pasaulē, arī Lietuvā psihiatriskā ārstniecība aizsākās divdesmitā gadsimta sākumā. Vēsturisku apstākḷu dēḷ psihiatriskās ārstniecības intensīvākās attīstības un nostiprināšanās laiks sakrita ar padomju okupāciju un tās programmu radikālai cilvēku dzīves pārveidei, kas savukārt noteica psihiatrijas attīstības virzienu un raksturu. Padomju veselības aprūpes sistēma, kas Lietuvā tika ieviesta pēc Otrā pasaules kara, aptvēra arī psihiatriju. Būt slimam nozīmēja būt atkarīgam no valsts. Tādējādi vara pār slimību bija vara pār cilvēku.

Institucionalizēta un līdz ar to valsts pārvaldīta, psihiatrija kḷuva par sociālpolitiskās varas instrumentu. Valsts iestādes palīdzēja noteikt un uzraudzīt konkrētu sabiedrības daḷ jeb tā sauktos garīgi slimos. Šāda psihiatrijas sistēma radīja fenomenu, ko var saukt par atkarību no iestādes - cilvēkiem arvien biežāk tika atklāti garīgi traucējumi un bija nepieciešama psihiatriskā aprūpe. Slimnīcas bija pārpildītas, bet šī problēma tika risināta, atverot arvien jaunas slimnīcas. Padomju okupācijas rezultātā Lietuvas psihiatrija tika ievilkta padomju psihiatrijā, nošķirta no rietumu pasaules ietekmes un spiesta darboties saskaņā ar padomju modeli. Tomēr padomju psihiatrija nebūt nebija virspusēja. Tās centros - Maskavā un L,eņingradā - tika izveidoti standarti, kuros bija pieḷaujamas nelielas variācijas viena psihiatrijas modeḷa robežās, starp konkurējošiem virzieniem atstājot vien šauras un nosacītas izvēles iespējas. Lietuvas PSR sociālkulturālā vide un pirmskara tendence sekot Vācijas psihiatrijas tradīcijām veicināja psihiatrijas īpatnību attīstību Lietuvā. Padomju Savienības perifērijā šīs īpatnības un nelielās variācijas dažādās slimnīcās 
attīstījās saspīlējumā starp divām galvenajām ietekmēm - Maskavas un L,eņingradas, t. i., konservatīvo biomedicīnisko terapiju un liberālo psihoterapiju. Neraugoties uz nošķirtību no rietumu pasaules, padomju un Lietuvas psihiatrija nebija pilnībā nošķirtas no rietumu ietekmes un notiekošajām pārmaiņām, piemēram, psihofarmakoloǵijas attīstības vai rietumu pasaulē izskanējušā viedokḷa par iespējamo institucionalizācijas kaitējumu pacientiem. Tomēr jaunas globālas tendences psihiatrijā varēja nonākt tikai padomju versijā.

Konceptam "vara pār slimību”, ko radīja padomju psihiatriskās aprūpes sistēma, bija tumšā puse. To iemiesoja paralēlisms - psihiatrisko slimnīcu neterapeitiskās funkcijas un to attīstība. Valsts vara pār slimību, līdz ar to pār cilvēku, izpaudās kā tieša politiska vara, psihiatriju izmantojot politiskiem mērķiem. Tomēr vēl būtiskāk - daži pilsoṇi, atdarinot valsts rīcību, izmantoja padomju neformālo praksi, lai ar psihiatrijas palīdzību aizstāvētu savas intereses. Neapšaubāmi, ka procesiem, kas bija raksturīgi padomju psihiatrijai, atsevišksās republikās bija savas īpatnības. Režīms sliecās izrēḳināties ar politiskajiem pretiniekiem, izmantojot "tradicionālās" represijas metodes, savukārt cilvēki, lai izvairītos no valsts uzliktajiem pienākumiem, izmantoja psihiatriju.

Padomju psihiatriskās aprūpes sistēma atspoguḷo arī padomju valsts un tās pilsoṇu savstarpējo attiecību attīstību. Var teikt, ka neviens no padomju pilsoņiem nebija tik paradoksālā situācijā kā cilvēks, kurš tika atzīts par garīgi slimu. Valsts kontrolēja ikvienu cilvēka dzīves aspektu, bet pār garīgi slimu cilvēku valstij bija vēl lielāka vara. Tomēr vienlaikus "garīgi slims" cilvēks atradās ārpus valsts kontroles citos aspektos, jo tika atbrīvots no dažiem pienākumiem, saistībām un soda, kas attiecās uz "normāliem pilsoņiem”. Tādējādi nonākšana kontroles iestādēs bija veids, kā izvairīties no kontroles. Cilvēki mēǵināja atgūt varu, izmantojot valsts bezspēcību, tādēḷ Padomju Lietuvas psihiatrijas vēsturi caurvij vara pār slimību un slimība pār varu.

\section{Tomas Vaiseta}

Dr., asociētais profesors, Viḷnas Universitātes Vēstures fakultāte, Lietuva / Associate Professor, Vilnius University, Faculty of History, Lithuania 